\title{
Study on the distribution of international tax benefit under the environment of e-commerce
}

\author{
Yunji Liang ${ }^{1, a}$, Lijun Bu ${ }^{2, b}$ \\ ${ }^{1}$ School of Accounting, Harbin University of Commerce, Harbin 150028, China; \\ 2 School of Accounting, Harbin University of Commerce, Harbin 150028, China. \\ a liangyunji@126.com, b bulijun@126.com
}

Keywords: E-commerce, International tax benefit, Permanent establishment.

\begin{abstract}
The burgeoning development of e-commerce on a global scale exposes theories and systems of international tax to a series of tough challenges. Traditional criterion and practices of international tax find it difficult to take effective roles under such environment of e-commerce, which leads to significant changes in the pattern of distribution of international tax benefit. Herein, reasonable adjustments to current principles and methods of distribution of international tax benefit should be necessarily implemented and benefit sharing mechanism of international tax adaptable to the development of e-commerce should be established to guarantee the tax benefit all over the world.
\end{abstract}

\section{Shock to distribution of international tax benefit by e-commerce}

Traditional concepts like the definition of residents, permanent establishment and territorial jurisdiction fail to exert their confinement function while traditional criterion and practices of international tax find it difficult to take effective roles under such environment of e-commerce, which lead to significant changes in the pattern of distribution of international tax benefit.

A. Impact on distribution of international tax benefit through income tax by e-commerce

1)Continuous shrink of the right of taxation of income source

a)In the aspect of independent personal service income: Due to the more convenient technological base of multinationalization provided to independent personal service by the form of e-commerce, more and more independent personal service will choose the way in which independent personal service is provided directly on internet rather than the way in which independent personal service is provided in the service acceptance nation which is currently relatively popular. However, the independent personal service which is judged to have fixed basis in the service acceptance nation is reducing, which causes the actual narrowing of the right of taxation of income source on independent personal service income.

b)In the aspect of income from transfer of property: As is stipulated by current regulations, the right of taxation to income from portfolio transfer, shares transfer, etc. is owned by the residential country of transferer instead of the nation to which transfer place belongs. With the emergence and development of e-commerce, multinational activities of buying and selling securities such as bonds and shares directly are increasing. The principle of taxation by income source (the nation to which transfer place belongs) will intensify the conflict caused by transferring tax benefit to the residential country of transferer.

c)In the aspect of passive investment: Due to the emergence and development of e-commerce, the situations like separate transfers of industrial property or permit using are reducing while those like simultaneous provision of both transfer of industrial property or permit using and technical service are increasing. Therefore, some income in form of franchise will transfer the business income by changing the existing form. Also, that will have an impact on the tax benefit of income source on income from franchise.

2)Influence on the worldwide implementation of right of taxation imposed by functional contraction of permanent establishment 
As an important concept of international tax, permanent establishment is proposed to confirm the right of taxation on profit gained by enterprises or their branches of a contracting state imposed by the other contracting state. Permanent establishment is defined by both OECD model and UN model as: the fixed place of business in which all or partial business activities are carried out. Complying to the current rules of international tax, the income source could only execute its right of taxation on business income of permanent establishment set by multinational enterprise, however, with the arising of e-commerce, functions of permanent establishment according to current concepts are now shrinking. Multinational trading doesn't call for a guarantee of permanent establishment, provision of most products and labor service do not need the actual "presence" of enterprises, instead, a website and a software allowing relevant trading are enough for a multinational enterprise to accomplish the entire process of trading. Moreover, a website could not be judged to be commercial or uncommercial depending on the domain name alone due to the remote relationship between the website on internet and the identities as well as locations of two trading parties. Hence, it is difficult to assure whether there is a permanent establishment, what is the business address of taxpayers, where is the place of tax payment, thus a large quantity of tax revenue are lost.

3)Redistribution of international tax benefit caused by aggravated conflict of tax jurisdiction

Conflict of tax jurisdiction mainly refers to the conflict between source jurisdiction and domiciliary jurisdiction to tax, the consequently international double taxation is usually avoided by bilateral tax agreement. However, the development of e-commerce, on one hand, weakens the tax jurisdiction of income source and leads to conflicts in worldwide judgment of income source; on the other hand, the development of e-commerce also complicates the confirmation of identities of residents, such as the differentiation of registration place and control place of internet enterprises. All those influences produce new conflicts of tax jurisdiction on origin basis.

a)Severe shock is imposed to domiciliary jurisdiction: Is there "residence", "management center" or "control center" are adopted as criterion to confirm the residence identity of taxpayer. However, e-commerce surpasses the limitation of time and space, accelerates the integration of international trading, challenges the concepts of "residence" and "permanent establishment" and causes the diversification, fuzzification and marginalization. With the emergence of e-commerce, integration of international trading and wide application of various advanced technical means, the management and control center of enterprises could possibly exist in any country, tax authorities would find it hard to collect income tax to enterprises complying to nationality principle and domiciliary jurisdiction to tax would exist in name only.Change number of columns: Select the "Columns" icon from the MS Word Standard toolbar and then select "1 Column" from the selection palette.

b)Weakening of source jurisdiction caused by development of e-commerce: Source jurisdiction to tax has been invalid because of digitalization, visualization, concealment of trading, electronization of payment, difficult judgment of trading place, provision and utilization of products and service in e-commerce. During the launch of trading in one country by a foreign enterprise through internet, only an intelligent server generally speaking, with approval software installed in advance is needed to buy and sell digitalized products, thus business behaviors of server is hard to be classified and counted, traders are also difficult to be confirmed. In addition, the appearance of internet helps service break the restraint of regions and allows the supplier of service to be in remote place, which consequently causes worldwide conflict in judging the source of income. In order to protect their sovereignty and economical interest, each government definitely focus on maintain their interest through taxation which brings quite huge difficulty to the implementation of source jurisdiction to tax and intensifies conflict in international tax jurisdiction.

B. Impact on distribution of international tax benefit imposed by e-commerce through turnover tax

In the aspect of turnover tax, the principle of consumption place finds serious difficulty in implementation. In international e-commerce, consumption place will face various barriers to collect tax on products traded online because all trading processes are operated on internet and leave rarely traces in reality; then in offline trading, products of exporting enterprise would probably sold to sporadic consumers in various importing countries because of the separation of purchasing and selling places and indirect contact between trading parties. In this way, it's very hard for consumption 
place to collect tax on all consumers. Hence, direct importing activities under condition of e-commerce will be more and more popular while extreme low work efficiency and high cost of taxation would be created by the direct taxation of taxation tax on consumers. Comparatively speaking, collection of tax by selling countries caters more to the requirement of efficiency.

C. Impact on distribution of international tax benefit imposed by duty free policy of e-commerce

Since developed countries adopt direct tax as main part of their tax system, the duty free policy of e-commerce will not only has no big shock to the existed tax system, but also promotes the development of the development of e-commerce in those countries. However, developing countries take indirect tax as it main part of tax system, exemption of tax especially turnover tax to e-commerce would bring burden to these countries much heavier than that of countries taking direct tax as main tax. In the traditional economic pattern, all tradings among countries could reach a balanced state. However under the environment of e-commerce, as most developing countries are importing countries of e-commerce, they would probably become the net importers of tax burden if duty free policy is applied to e-commerce. Consequently, developing countries would be in a very passive situation in the distribution pattern of international income leaded by e-commerce.

\section{Adjustment of international tax benefit}

A. Reasonable adjustment to current principles and methods of international tax benefit

The core problem of establishing new order of international tax is to find a new distribution method of tax benefit based on specific national conditions of different countries and in accordance to which the division of tax benefit among countries shall be carried out.

1)Redefinition of permanent establishment

According to the current concept, permanent establishment could be divided into the one consists of fixed business place and the other composed of business agent. From the view of development of permanent establishment, object (permanent establishment consisting of fixed business place) and people (permanent establishment composed of business agent) are always crucial elements of permanent establishment, no matter how the concept of permanent establishment changes. On international internet, both the elements of object and people would still exist no matter how e-commerce develops. Therefore, new definitions of concept of current permanent establishment and criterion should necessarily be made under the environment of e-commerce.

a)Permanent establishment could be composed of website, server reserving website and supplier: Whether the website and server reserving website should be permanent establishment is judged by the fact that whether the website and server reserving website could accomplish main or significant business activities and whether they have certain stability. In e-commerce, the automatic function of internet technology could guarantee the website and server reserving website to accomplish enterprise's business activities from source country regardless of non-existing of employees. Therefore, this website and server reserving website could be confirmed as the business place set in source country by residential country. Generally, website and server reserving website is stable to an extent, related to certain geographical location, fixed in existing space and constant in time. Changes of website and serer reserving website are mainly to evade tax instead of being determined by the nature of internet trading itself and could not deny the fixity of website and server reserving website.

b)Supplier of internet could form a business agent of independent position and then the permanent establishment : Generally, supplier of internet set up servers to provide internet service of various forms. Relatively to sales person, supplier of internet runs his business following business practices of his own with a completely independent position. Herein, the activity that supplier of internet provide server to help sales person carry out business could be regarded as a kind of agency activity. In this way, this supplier of internet should be considered as an agent of independent position and could constitute a permanent establishment of sales person.

2)Division method and standard of adjustment to business profit and franchise royalty fee

This work of adjustment could be carried out in reference to the method and standard of used to classify the taxable activities of providing digital products for a fee mentioned above. All income 
gained from selling products and providing labor service should be regarded as business profit; all income gained from transferring permission right of use of industrial property which is legally protected for a fee should be confirmed as franchise royalty fee.

3)Adjustment to applicable range of principles of domiciliary jurisdiction and source jurisdiction

Applicable range of principle of source jurisdiction should mainly be enlarged while that of domiciliary jurisdiction should be narrowed. Main content is following: all independent personal service income provided by internet should be classified to the range of source jurisdiction; income from transferring the ownership of franchised right on internet, income from transfer of property like transferring of portfolio should be included by the range of source jurisdiction; income from providing labor service on internet, at least the income from providing technical service should be contained by the range of source jurisdiction. Meanwhile, the prior application of source jurisdiction should be further confirmed and obligations of contracting countries to avoid international double taxation when domiciliary jurisdiction is applied after the prior application of source jurisdiction.

B. Further improvement and reinforcement of cooperation and coordination in international taxation

Under traditional environment, the range if international taxation is mainly limited to solve problems of double taxation on capital and individual income flowing among countries caused by overlap of tax jurisdiction worldwide. Basic standards obeyed by nations worldwide and distribution pattern of benefit have been formed in aspect of distribution of international taxation by international long-term cooperation and competition. But to multinational trading under the environment of e-commerce, the concept of country identity has been weakened gradually, besides, nearly taxation of every country follows its trading closely to go out of the country and integrates with taxation of other countries to form the "internationalization" of tax base, based on which, a new range of international taxation much larger than the former is composed. Therefore, standards and practices of international taxation developed under the environment of are hard to be implemented effectively, which consequently leads to significant changes in distribution pattern of international tax benefit. That requires objectively that every government should start from the longterm interest of its own to build a more comprehensive, further and more effective coordination and cooperation with other countries, that is, to establish a new framework of international tax system with more obvious characteristic of integration and adaptability to economic globalization in order to regulate and coordinate the problems concerning tax on internet trading all over the world.

\section{References}

[1]. Christopher G.Reddick, Jerrell D.Coggburn. E-commerce and the Future of the State Sales Tax System: Critical Issues and Policy Recommendations[J]. International Journal of Public Administration, 2007, Vol.30 (10)

[2]. Chen Weidong. Impact on current tax system imposed by e-commerce[J]. Tax administration, 2008, (10).

[3]. Zhu Yansheng. Discussion on international taxation in internet economy[J]. International taxation, 2009, (2).

[4]. Lei Chao. Shock and challenge to international tax law by e-commerce[J]. Tax research, 2010, (11).

[5]. Kathleen Hale,Ramona McNeal.Technology, politics, and e-commerce: Internet sales tax and interstate cooperation[J]. Government Information Quarterly, 2010, Vol.28 (2):262-270 